九州大学学術情報リポジトリ

Kyushu University Institutional Repository

\title{
Estimation of Consumptive Use of Crops in the Sistan Farm-land Development Project, Iran
}

Fuj ikawa, Takenobu

Laboratory of Land Improvement and Conservation Engineering, Faculty of Agriculture, Kyushu University

Higuchi, Shoichiro

Department of Kage-Sanyu Group of Consulting Engineers, Iran

Kaku, Ken

Agicultural Construction Engineering, Faculty of Agriculture, Saga University

https://doi.org/10.5109/23672

出版情報: 九州大学大学院農学研究院紀要. 23 (1/2)，pp.1-11，1978-10. Kyushu University バージョン：

権利関係 : 


\title{
Estimation of Consumptive Use of Crops in the Sistan Farm-land Development Project, Iran
}

\author{
Takenobu Fujikawa. Sboicbiro Higuchi* \\ and Ken Kaku** \\ Laboratory of Land Improvement and Conservation Engineering, \\ Faculty of Agriculture, Kyushu University 46-05, Fukuoka 812
}

(Received February 4. 1978)

\begin{abstract}
The Sistan project area is located at the south-east district of Iran near the border to Afganistan, belongs to the arid zone and the climate condition is particular. In this area, an huge farm land development project have been planned by using the water of Hermand river for irrigation. The most important factor to establish the irrigation plan is to estimate the consumptive use of the crops, which will be introduced in this area. Studying several methods, the Penman method was concluded as the most suitable one to estimate the consumptive use of crops in the area.
\end{abstract}

\section{INTRODUCTION}

Almost all the parts of Iran are in the arid or semi-arid zone, so that there is scarcely rain fall which is to be used as effective agricultural water. Therefore, irrigation water should rely on some artificial facilities. They have been wrestled with the wide scale development of water resouces since 1960. As the results, over one million hectares of uncultivated land have gained the potential to be developed as farm land. However, there are many problems, which should be clarified hereafter, in connection with how to use this developed water effectively, or how to attain the maximum irrigation effect by the minimum amount of water. Investigations and discussions on severals of these problems, such as the consumptive use of crops, the irrigation method and the method of water management, have been started. This paper describes the investigation on the estimation of the consumptive use of crops for the Sistan project area as one of these problems.

The accurate and practical value of the consumptive use of a crop should be determined by a field experiment. However, there are not any facilities for such experiment and they have scarcely planted any crops in the project area, so that presumption is necessary for the estimation of the value for this area. The climate condition of a place in the arid zone is significantly

\footnotetext{
* Director of Technical Research, Department of Kage-Sanyu Group of Consulting Engineers, Iran.

** Professor, Agicultural Construction Engineering, Faculty of Agriculture, Saga University.
} 
influenced by its location. Therefore, the consumptive use of crops will be also influenced by the location. Although there are many uncultivated lands in Iran, the extent of the area which can be developed to farm land is restricted by the available amount of water. For the effective and successive farmland development, it is necessary to presume the consumptive use of crops accurately.

\section{CHARACTERISTICS OF THE PROJECT AREA}

\section{Location}

The Sistan project area is located at the south east part of Iran near the border of Iran-Afganistan and has the area of 250,000 hectares (Fig. 1). It is the inland delta formed by the flow of the Helmand River, the basin of which is in Afganistan, and is in the arid zone. The flood water of melted snow of the Helmand River flows into the south west part of the delta in spring and makes a vast lake. The lake, having the water depth of 1-l. 5

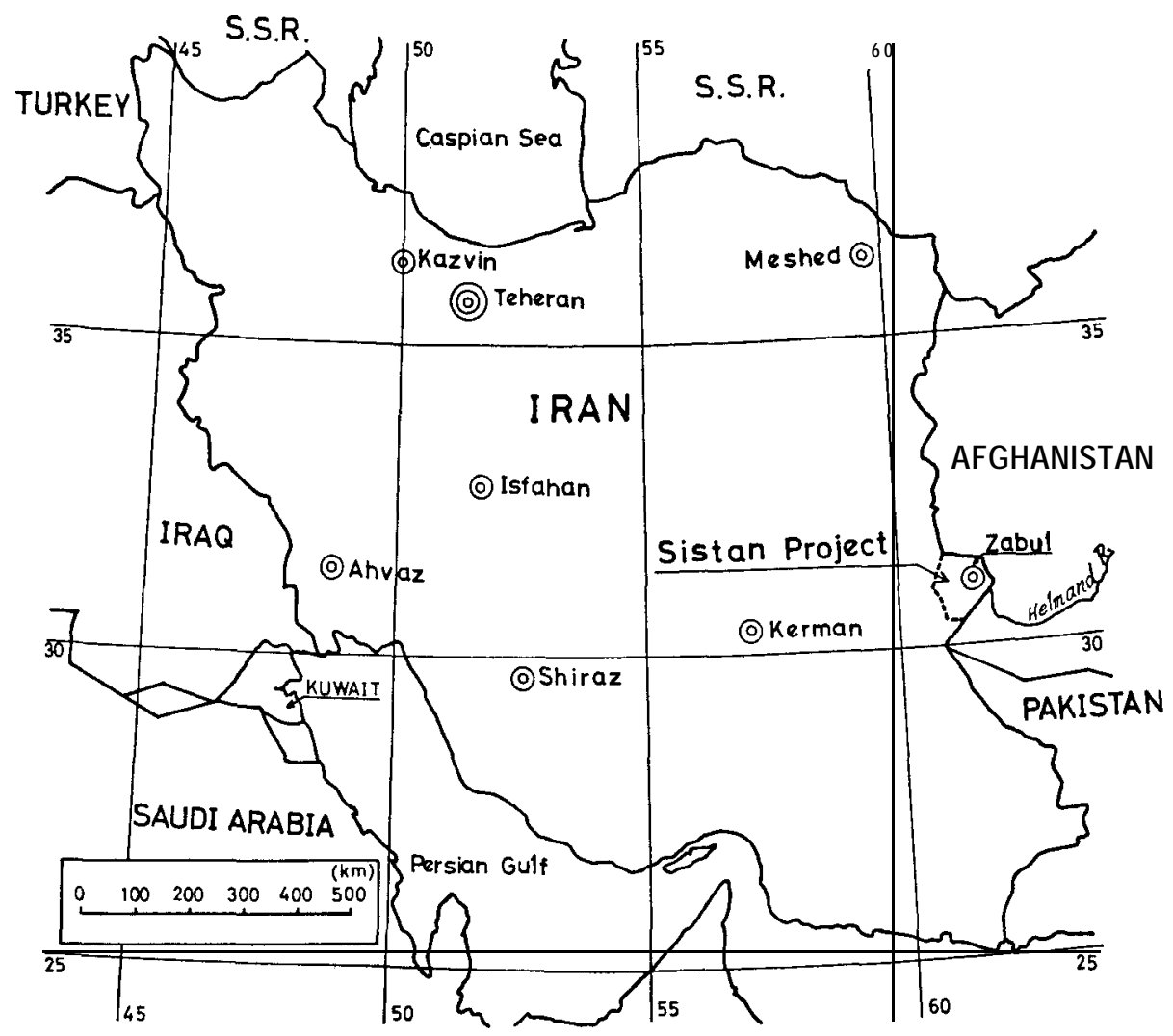

Fig. 1. Location of the Sistan project area. 
meters, is 40 Kilometers from east to west and 100 Kilometers from south to north. In summer, the discharge of the Helmand River becomes almost zero because there is a reservoir at the upstream of it in Afganistan. Therefore, summer farming is impossible and they can cultivate crops only in spring.

The object of the Sistan project is to introduce summer crops in the area, by storing the spring water in the Chahnime Reservoir which is planned to be constructed at the upstream of the river, and by using this water for irrigation throughout the year. Sugarbeets, oil plants, pastures and vegetables, which have never been cultivated in the area, are planned to be introduced.

\section{Climate condition}

The climate condition of the area has the typical characteristics of the arid zone. Namely, the summer temperature is $30^{\circ} \mathrm{C} \sim 45^{\circ} \mathrm{C}$, the winter temperature is $0^{\circ} \mathrm{C} \sim 5^{\circ} \mathrm{C}$, the annual precipitation is about $55 \mathrm{~mm}$ and the annual evaporation is about 4,800 $\mathrm{mm}$ (Table 1 ). In addition, there are north winds on 120 days per a year, which average velocity is about $6 \sim 8 \mathrm{~m} / \mathrm{sec}$. The larger value of the annual evaporation comparing with these $(3,000 \mathrm{~mm} \sim 3,500$ $\mathrm{mm}$ ) in the other parts of Iran, which temperature are also high, is probably caused by these north winds. The annual evaporation will have much effects on the consumptive use of crops, so that the consumptive use for the area will be very large. It can be said that the Sistan project area is in the worst climate condition among principal agricultural areas in Iran (Table 2).

Table 1. Climate conditions of Sistan project area.

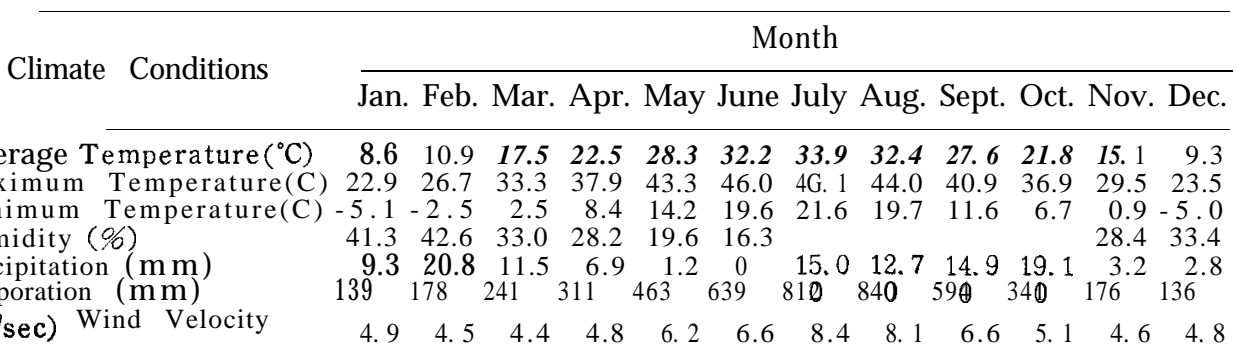

Annual Precipitation 55. $7 \mathrm{~mm}$, Annual Evaporation 4,870 mm.

Table 2. Climate conditions of the principal farmland development areas in Iran. (1) Average temperature $\left({ }^{\circ} \mathrm{C}\right)$

\begin{tabular}{|c|c|c|c|c|c|c|c|c|c|c|c|c|}
\hline \multirow{2}{*}{ Name of Area } & \multicolumn{12}{|c|}{ Month } \\
\hline & Jan. & Feb. & Mar. & Apr. & May & June & July & Aug. & Sept. & Oct. & Nov. & Dec. \\
\hline Kazvin & 0.5 & 3.0 & 9.1 & 12.9 & 19.7 & 24. 1 & 26.9 & 27. 0 & 22. 6 & 16. 5 & 10.3 & 5.4 \\
\hline Meshed & 3.5 & 2.2 & 8.2 & 13.7 & 19.2 & 23.7 & 25.3 & 23.7 & 19.5 & 14.1 & 8.4 & 3.5 \\
\hline Isfahan & & 5.8 & 11. 1 & 14.3 & 17. 4 & 26. 2 & 28.8 & 27.3 & 19.0 & 17. 0 & 10.1 & 4. 6 \\
\hline Kerman & 3.7 & 5.9 & 11.2 & 15.9 & 21.4 & 25.5 & 26.3 & 24.4 & 20.1 & 15.7 & 8.9 & 4.8 \\
\hline Ahvaz & 12.5 & 13.1 & 17.2 & 22.4 & 30.5 & 33.6 & 35.7 & 35.2 & 26.8 & 27.5 & 19.2 & 13.5 \\
\hline Zabol (Sistan) & 8.6 & 10.9 & 17.5 & 22.5 & 28.3 & 32.2 & 33.9 & 32.4 & 27.6 & 21.8 & 15.1 & 9.3 \\
\hline
\end{tabular}


(2) Humidity (\%)

Month

\begin{tabular}{|c|c|c|c|c|c|c|c|c|c|c|c|c|}
\hline \multirow{2}{*}{ Name of Area } & \multicolumn{12}{|c|}{ (1) } \\
\hline & Jan. & Feb. & Mar. & Apr. & May. & June & July & Aug. & Sept. & Oct. & Nov. & Dec \\
\hline Kazvin & 66 & 63 & 57 & 56 & 48 & 38 & 39 & 36 & 39 & 53 & 60 & 62 \\
\hline Meshed & 72 & 74 & 69 & 58 & 45 & 36 & 32 & 30 & 34 & 53 & 62 & 68 \\
\hline Isfahan & 60 & 52 & 41 & 41 & 31 & 20 & 21 & 20 & 24 & 31 & 49 & 58 \\
\hline Kerman & 61 & 54 & 48 & 36 & 25 & 19 & 16 & 28 & 23 & 27 & 39 & 44 \\
\hline & 70 & 70 & 54 & 52 & 37 & 30 & 32 & 39 & 37 & 49 & 62 & 70 \\
\hline Złaboz (Sistan) & 41 & 43 & 33 & 28 & 20 & 16 & 15 & 13 & 15 & 19 & 28 & 39 \\
\hline
\end{tabular}

(3) Precipitation $(\mathrm{mm})$

\begin{tabular}{|c|c|c|c|c|c|c|c|c|c|c|c|c|c|}
\hline \multirow{2}{*}{ Name of Area } & \multicolumn{12}{|c|}{ Month } & \multirow{2}{*}{ Total } \\
\hline & Jan. & Feb. & Mar. & Apr. & $\mathrm{Ma}$ & June & July & Aug. & $S$ & Oct. & Nov. & Dec. & \\
\hline Kazv & 53.7 & 28.3 & 46.3 & 52 & 32 & 6.5 & 2.2 & 5 & 2.9 & 27.3 & 42.9 & 28 & 330.2 \\
\hline Meshed & 25.6 & 24.2 & 45.1 & 35.0 & 20.0 & 1.7 & 1.6 & 0.2 & 1.4 & 14.0 & 19.9 & 23.9 & 212.6 \\
\hline Isfahan & 20.4 & 12.3 & 13.0 & 19.0 & 9 & 0 & 0 & & 0 & 68 & 9.5 & 9.7 & 999 \\
\hline $\mathrm{Ke}$ & 37.6 & 32.8 & 19.2 & 17.4 & 7.8 & 1.4 & 0.1 & 00.7 & 0.8 & $0{ }^{\prime} 4$ & 1. 6 & 9.7 & 129.5 \\
\hline $\mathrm{Ah}$ & 50.6 & 38.0 & 17.8 & 21.0 & 12.5 & 0 & 0 & 0 & 0 & $16: 4$ & 65.5 & 21.7 & 243.5 \\
\hline Zabol (Sistan) & 9.3 & 20.8 & 11.5 & 6.9 & 1.2 & 0 & & & & 0 & 3.2 & 2.8 & 55.7 \\
\hline
\end{tabular}

(4) Pan Evaporation ( $\mathrm{mm}$ )

\begin{tabular}{|c|c|c|c|c|c|c|c|c|c|c|c|c|c|}
\hline \multirow{2}{*}{ Name of Area } & \multicolumn{12}{|c|}{ Month } & \multirow{2}{*}{ - Total } \\
\hline & Jan. & Feb. & Mar. & Apr. & May & June & July & Aug. & Sept. & Oct. & Nov. & Dec. & \\
\hline $\begin{array}{l}\text { Ahvaz } \\
\text { Zabol (Sistan) }\end{array}$ & $\begin{array}{r}63 \\
139\end{array}$ & $\begin{array}{r}82 \\
178\end{array}$ & $\begin{array}{l}146 \\
241\end{array}$ & $\begin{array}{l}211 \\
311\end{array}$ & $\begin{array}{l}321 \\
463\end{array}$ & $\begin{array}{l}473 \\
639\end{array}$ & $\begin{array}{l}611 \\
812\end{array}$ & $\begin{array}{l}558 \\
840\end{array}$ & $\begin{array}{l}388 \\
594\end{array}$ & $\begin{array}{l}292 \\
341\end{array}$ & $\begin{array}{l}139 \\
176\end{array}$ & $\begin{array}{r}799 \\
136\end{array}$ & $\begin{array}{l}3,383 \\
4,870\end{array}$ \\
\hline
\end{tabular}

Remarks: Monthly Pan Evaporation data at other area is not shown due to the difficulty to collect the accurate data. The annual evaporation is estimated about 2,800-3,000 $\mathrm{mm}$ at the northern part of Iran and about 3,000-3,500 mm at the southern part of Iran. There is a few places like the Sistan area which has annual evaporation more than $4,500 \mathrm{~mm}$ in Iran.

\section{BLANEY-CRIDDLE METHOD}

The Blaney-Criddle method (Israelsen and Hansen, 1962) have been widely used to estimate the consumptive use of a crop in many countries. Also in Iran, they had used this method in almost all projects up to recent. The method uses the experimental formula, which was proposed by U. S. D. A. (Blaney and Criddle, 1962). They deduced this formula by analysing the correlation between the data of climate condition and that of consumptive use which had been obtained at many places in U. S. A. untill 1945. The consumptive use of a crop for a place is experssed by the functions of the temperature, the percentage of sunshine. the growth stage of the crop and the coefficient of the crop, as the equation (1). This formula has been considered to give fairly accurate values for the area in the arid zone. If the climate condition of the area is normal, this 


\section{Consumptive Use of Crops, Iran}

Table 3. Proposed monthly crop coefficients (K).

(1) Western. U. S. A.

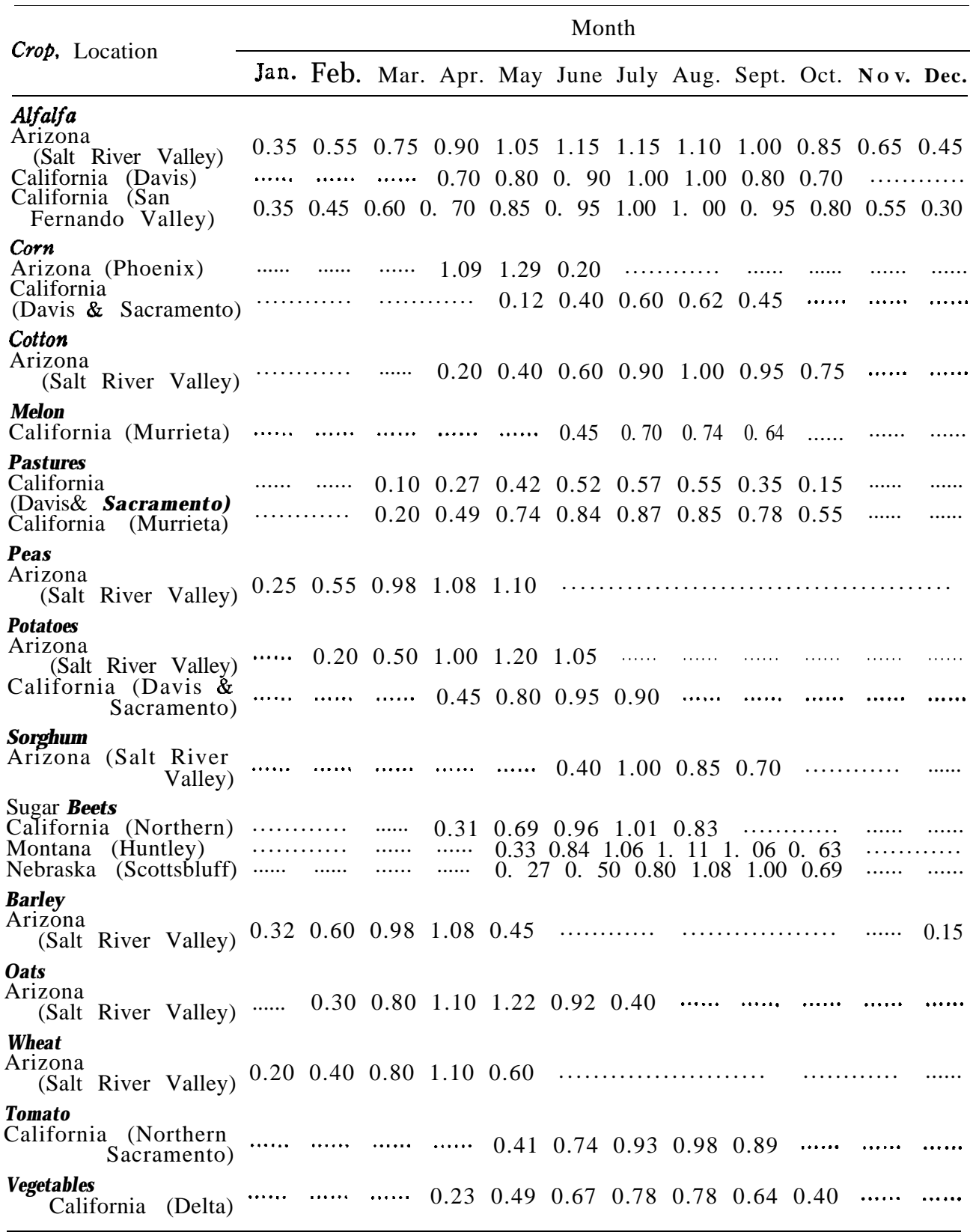

Remarks: These values of " $K$ " are quoted from Blaney and Criddle (1962). 
(2) Kazvin project area, Iran

\begin{tabular}{|c|c|c|c|c|c|c|c|c|c|c|c|c|}
\hline \multirow{2}{*}{ Name of Crop } & \multicolumn{12}{|c|}{ Month } \\
\hline & $\mathrm{n}$. & Feb. & Mar. & Apr. I & May $J$ & June & July & Aug. & Sept. & Oct. & Nov. & Dec. \\
\hline Wheat \& Barley & 45 & 0.60 & 0.80 & 1.00 & 0.80 & ...... & ...... & ...... & $\cdots$ & 0.30 & 0.40 & 0.50 \\
\hline Chick Peas & ,..... & $\ldots \ldots$ & $\ldots \ldots$ & 0.70 & 0. 90 & 0. 80 & $\cdots \cdots$ & ....... & $\cdots$ & $\ldots \ldots$ & $\cdots$ & $\cdots$ \\
\hline Sugar Beets & ...." & '...' & ...." & 0. 25 & 0. 50 & 0.80 & 0. 90 & 1.00 & 0.75 & & & \\
\hline Alfalfa & $\cdots \cdots$ & $\ldots \ldots$ & 0.50 & 0.80 & 0.90 & 1.05 & 0.95 & 0.95 & 0.80 & 0.60 & & \\
\hline Deciduous Orc & ...... & ...... & 0.35 & 0.55 & 0.70 & 0.80 & 0.80 & 0.80 & 0.60 & 0.35 & ... & \\
\hline Potatoes \& Onion & $\cdots \cdots$ & $\cdots \cdots$ & $\ldots \ldots$ & 0.20 & 0.60 & 0.80 & 0.95 & 0.90 & 0.75 & $\ldots \ldots$ & $\cdots \cdots$ & $\cdots$ \\
\hline Vineyards & $\cdots \cdots$ & $\ldots \ldots$ & ...... & 0.30 & 0.60 & 0.80 & 0.90 & 0.80 & 0.60 & 0.40 & & \\
\hline
\end{tabular}

$$
U=K \cdot P(0.46 t+8.13)
$$

$U$; monthly consumptive use of crop ( $\mathrm{mm} / \mathrm{month}$ )

$K$; empirical coefficient of crop

$P$; monthly percentage of daytime hours of the year

$t$; mean monthly temperature

method gives reasonable results. However, there is the difficulty of determining the coefficient of crop. The coefficient should be modified, if the climate condition of the project area is not similar to that of any experimented places.

Table 4. Consumptive use of each crop in $\operatorname{Iran}(\mathrm{mm})$.

Crop. Location $\frac{\text { Month. }}{\text { Jan. Feb. Mar. Apr. May June July Aug. Sept. Oct. Nov. Dec. Total }}$

\section{Wheat \& Barley}

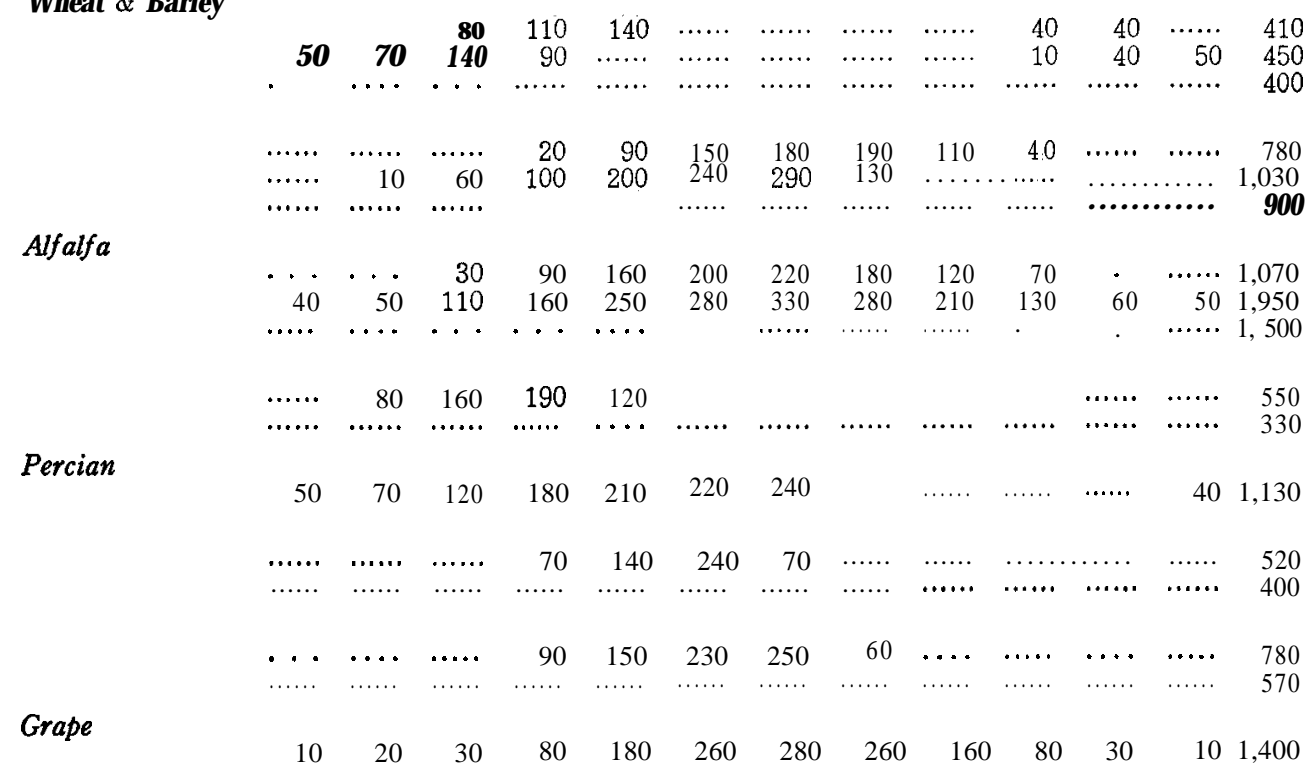

Remarks: Monthly data was not obtained in the crop of Ahvaz. 
Because the climate condition of the Sistan project area is particular, some modifications are necessary. Considering several actual values in Iran, they were modified as Table 3(2). Table 4 shows the consumptive use of crops estimated by using these $K$ values, which was adopted as standards at the early stage of the Sistan project.

\section{PENMAN METHOD}

Penman (1948), based on his experimental study on irrigation for meadow, mentioned that the ratio of the evapo-transpiration $\left(E_{p}\right)$ of a crop to the evaporation $(E$,$) from free water surface was constant and that the ratio E_{p}$ $/ E_{0}$ is 0.6 for the period of Nov.-Feb. (winter), 0.7 for Mar.-Apr. and Sept. -Oct. (spring and autumn) and 0.8 for May-Aug. (summer). Therefore, the consumptive use of a crop can be estimated, knowing pan evaporation and the growth period of the crop. However, there will be question in estimating

Table 5. Evaporation from pan and free water surface.

(1) Zabol at Sistan area

\begin{tabular}{|c|c|c|c|c|c|c|c|c|c|c|c|c|c|c|}
\hline \multirow{2}{*}{\multicolumn{2}{|c|}{ Evaporation }} & \multicolumn{12}{|c|}{ Month } & \multirow{2}{*}{ Total } \\
\hline & & Jan. & Feb. & Mar. & Apr. & May & June & July & Aug. & Sept. & Oct. & Nov. & Dec. & \\
\hline \multirow{3}{*}{\multicolumn{2}{|c|}{$\begin{array}{l}\operatorname{Pan}\left(E_{p}\right)(\mathrm{mm}) \\
\text { Free Water } \\
\text { Surface }\left(E_{n}\right)(\mathrm{mm}) \\
\text { Ratio }\left(E_{0} / E_{p}\right)\end{array}$}} & 139 & 178 & 241 & 311 & 463 & 639 & 812 & 840 & 594 & 341 & 176 & 136 & 4,870 \\
\hline & & 84 & & 146 & 228 & 372 & 411 & 512 & 481 & 354 & 232 & 117 & 84 & 3,116 \\
\hline & & 0.6 & 0.53 & 0.61 & 0.73 & 0.80 & 0.64 & 0.63 & 0.57 & 0.60 & 0.68 & 0.66 & \multicolumn{2}{|c|}{$\begin{array}{l}\text { Average } \\
0.620 .64\end{array}$} \\
\hline \multirow[t]{3}{*}{ (2) } & \multicolumn{14}{|l|}{ Ahvaz } \\
\hline & \multirow{2}{*}{ Evaporation } & \multicolumn{12}{|c|}{ Month } & \multirow{2}{*}{ Tot } \\
\hline & & Jan. & Feb. & Mar. & Apr. & May & June & July & Aug. & Sept. & Oct. & Nov. & Dec. & \\
\hline \multirow{3}{*}{\multicolumn{2}{|c|}{$\begin{array}{l}\operatorname{Pan}\left(E_{p}\right)(\mathrm{mm}) \\
\text { Free Water } \\
\text { Surface }\left(E_{0}\right)(\mathrm{mm}) \\
\text { Ratio }\left(E_{0} / E_{p}\right)\end{array}$}} & 63 & 82 & 146 & 211 & 321 & 473 & 611 & 558 & 388 & 292 & 199 & 99 & 3,383 \\
\hline & & 56 & 78 & 121 & 177 & 242 & 279 & 295 & 276 & 210 & 151 & 84 & 53 & 2,022 \\
\hline & & 0.89 & 0.95 & 0.83 & 0.84 & 0.75 & 0.59 & 0.48 & 0.49 & 0.54 & 0.52 & 0.42 & \multicolumn{2}{|c|}{$\begin{array}{l}\text { Average : } \\
0.540 .65\end{array}$} \\
\hline
\end{tabular}

(3) Sistan project area in Iran

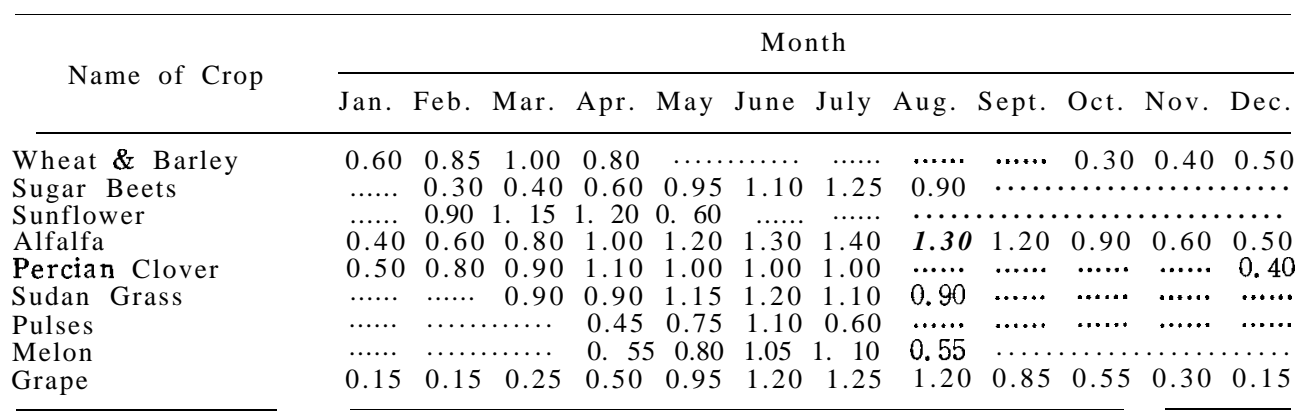

Remarks : These values of " $K$ " is determined by our study. 
evaporation from free water surface based on pan evaporation. Namely, evaporation from free water surface is almost the same as pan evaporation in the humid zone, while the one differs significantly from the other in the arid zone especially in summer. Table 5 shows comparisons of the values of pan evaporation and these of evaporation from free water surface obtained at the Sistan area and Ahvaz area, both of which are on the same latitude. Furthermore, the ratio $E_{p} / E_{0}$, which is considerd as constant for each seasons, corresponds to the $\mathrm{K}$ value of the Blaney-Criddle method and may vary with the species and the growth stage of the crop. Therefore, it is unreasonable to apply this method to the area in the arid zone.

Beside the above method, Penman (1956) proposed the theoretical equation, by which evapo-transpiration could be calculated from radiant energy of sun and wind velocity. The equation seemed to be reasonablly applied to the area in the arid zone, because it considered almost all the factors of climate condition, but it was so complicated that it was not practical. Slabbers (1969 a, b) obtained a practical equation to estimate evapo-traspiration, studying the data of the consumptive use of crops in Iran and modifying the Penman's equation. This method may be applied adequately to the Sistan project area.

The modified Penman method is summarized as follows.

(I) Evaporation from free water surface

$$
E_{0}=\frac{\left(\Delta \cdot H_{n t} / L\right)+\gamma E_{a}}{\Delta+\gamma}
$$

$E_{0}$; evaporation from free water surface (mm/day)

$A$; slope of saturation vapor-pressure versus temperature curve at the absolute temperature $\boldsymbol{T}$

$H_{n t}$; radiation energy $=\left(1-\gamma_{w}\right) R_{i}-R_{u}\left(\mathrm{cal} / \mathrm{cm}^{2} /\right.$ day $)$

$r_{w}$; reflection factor of water $(0.05)$

$R_{i}$; radiation energy of short wave $=(0.25+0.54 \mathrm{n} / \mathrm{N}) Q_{n}\left(\mathrm{cal} / \mathrm{cm}^{2} /\right.$ day $)$

$\boldsymbol{R}$, ; radiation energy of long wave $=\gamma_{T}^{4}\left(0.56-\mathrm{O} .092 \sqrt{e_{z}}\right) \cdot(\mathbf{0} .10+0.90 \mathrm{n} / \mathrm{N})$ (cal $/ \mathrm{cm}^{2} /$ day)

$Q_{n}$; theoretical max. radiation energy from soil surface (cal $/ \mathrm{cm}^{2} / \mathrm{day}$ )

$n$; measured sunshine duration (hour)

$N$; max. of possible sunshine duration (hour)

$\boldsymbol{e}_{z} ;$ average vapor pressure in air $=\left(E_{z} \cdot h_{z}\right)(\mathrm{mm} \cdot \mathrm{Hg})$

$E_{z} ;$ saturated vapor pressure at mean temperature $(\mathrm{mm} \cdot \mathrm{Hg})$

$h_{2}$; humidity, $r$; constant $(0.485)$

$T$; absolute temperature, $\left(T_{2}+273\right)^{\circ} \mathrm{C}$

$L$; latent heat of water vapor

$E_{a}$; drying power of air $=0.35\left(E_{z}-e_{z}\right)$

$U_{2}$; wind velocity at the point with the height of 2 meters above ground surface, (if this data is not available, the following equation may be used)

$$
U_{2}=U \frac{0.8}{\log h+0.5}(\mathrm{~m} / \mathrm{sec})
$$

$\boldsymbol{U}$; wind velocity at the point with the height of $\boldsymbol{h}$ meters above ground 
surface

The values of evaporation from free water surface calculated by the equation (2) for each places in Iran are shown in Table 6. The value for the Sistan project area is significantly larger than these for other places. The wind velocity is high and the humidity is low in the Sistan project area, so that the value of transpiration becomes larger and therefore the consumptive use of crops will be large (Van te Chow 1964). If the Blaney-Criddle method is used, the values of consumptive use of crops for the Sistan area and the Ahvaz area will be about same, because the temperature and the latitudes of both areas are about same, and only duration of sunshine and temperature are taken into account in the method.

Table 6. Evaporation from free water surface in $\operatorname{Iran}\left(E_{0}\right)$.

\begin{tabular}{|c|c|c|c|c|c|c|c|c|c|c|c|c|c|}
\hline Name of City & $\begin{array}{l}\text { Jan } \\
-31\end{array}$ & $\begin{array}{c}\text { Feb } \\
-45\end{array}$ & Mar. & Apr. & May. & June & July & Aug. & Sept. & Oct. & $\begin{array}{r}\text { Nov } \\
50\end{array}$ & Dec. & Tot \\
\hline Ghazuvin & 28 & 42 & 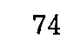 & 114 & 174 & 222 & 236 & 214 & 153 & 96 & 42 & 28 & 1,42 \\
\hline Mashad & & & 10 & 114 & 180 & 22 & 246 & 208 & 147 & 87 & & 25 & 5 \\
\hline Isfahan & 40 & 59 & & 138 & 189 & 228 & 242 & 220 & 168 & 115 & 60 & 37 & 1,6 \\
\hline Kerman & 47 & 67 & 112 & 144 & 189 & 219 & 229 & 208 & 159 & 118 & 66 & 47 & 1,605 \\
\hline Ahwaz & 56 & 78 & 121 & 177 & 242 & 279 & 295 & 276 & 210 & 151 & 84 & 53 & 2,022 \\
\hline Zabol (Sistan) & 84 & 95 & 146 & 228 & 372 & 41 & 512 & 489 & 354 & 232 & 117 & 84 & 3,1 \\
\hline
\end{tabular}

\section{(2) Consumptive use of crops}

In general, the evapo-transpiration of a crop will be given by the equation (3), in which the

$$
E_{p}=f \cdot E_{0}
$$

$E_{p} ;$ evapo-transpiration ( $\mathrm{mm} /$ day)

$E_{0}$; evaporation from free water surface $(\mathrm{mm} /$ day) coefficient of the crop $f$ should be determined by experiments. If the value of $f$ is unknown, it should be assumed empirically as the Blaney-Criddle method. The equation (4) was proposed to cover this deficiency.

Table 7. The relation between height of crop and $g(1)$, and wind velocity at $2 \mathrm{~m}$ above ground surface and $\mathrm{h}(\mathrm{U})$.

\begin{tabular}{cccc}
\hline Height and $\mathrm{g}(1)$ & Wind velocity at $2 \mathrm{~m}$ above ground surface $(U)$ \\
\hline Height of crop & Value of $\mathrm{g}(\mathrm{l}) \begin{array}{l}\text { Wind velocity at } \\
2 \mathrm{~m} \text { above ground } \\
\text { surface (m/sec) }\end{array}$ & Value of $\mathrm{h}(\mathrm{U})$ \\
\hline Ocm & 0.18 & 0.5 & 1.32 \\
$2 \mathrm{~cm}$ & 0.23 & 1.0 & 1.17 \\
$5 \mathrm{~cm}$ & 0.47 & 1.5 & 0.96 \\
$10 \mathrm{~cm}$ & 0.74 & 2.6 & 0.90 \\
$20 \mathrm{~cm}$ & 1.00 & 2.5 & 0.86 \\
$30 \mathrm{~cm}$ & 1.12 & 3.0 & 0.79 \\
$40 \mathrm{~cm}$ & 1.22 & 4.0 & \\
$50 \mathrm{~cm}$ & 1.32 & 5.0 & \\
$70 \mathrm{~cm}$ & 1.42 & & \\
$90 \mathrm{~cm}$ & 1.50 & & \\
\hline
\end{tabular}




$$
E_{p}=\left[1+a+c\left\{f\left(z_{0}, d\right)-0.28\right\}\right] E_{0}+d\left\{f\left(z_{0}, d\right)-0.28\right\}-b
$$

$f\left(z_{0}, d\right)$; function of the height of crop and wind velocity, namely $f\left(z_{0} \cdot d\right)=$ $g(l) \cdot h(U)$, the values are shown in the Table 7

$a, b, c, d$; constants by the climate condition of the area, the values are shown in the Table 8 for several principal places in Iran The consumptive use of crops for the Sistan project area by the equation (4) are obtained as Table 9.

Table 8. Value of $a, b, c$ and $d$ in Iran.

\begin{tabular}{lcccc}
\hline & (a) & (b) & (c) & (d) \\
\hline Ghazvin & 0.20 & 0.15 & 0.62 & 0.80 \\
Mashad & 0.20 & 0.16 & 0.73 & 0.40 \\
Isfahan & 0.21 & 0.15 & 0.79 & 0.80 \\
Kerman & 0.21 & 0.14 & 0.89 & 0.76 \\
Ahvaz (Sistan) & 0.18 & 0.27 & 0.70 & 0.50 \\
Zabol (Siar & 0.19 & 0.28 & 0.76 & 1.40 \\
\hline
\end{tabular}

Table 9. Consumptive use of crops by Penman method (mm).

\begin{tabular}{|c|c|c|c|c|c|c|c|c|c|c|c|c|c|}
\hline Crop & Jan. & Feb. & Mar. & Apr. & May & June & July & Aug. & Sept. & Oct. & Nov. & Dec. & Total \\
\hline \multirow{2}{*}{ Whea } & 42 & 62 & 145 & 155 & - & $m$ & & 一 & - & 21 & 45 & 4 & \\
\hline & 3 & 59 & 130 & 134 & 一 & - & - & - & - & & & & 55 \\
\hline \multirow{2}{*}{ Sugar Beet } & 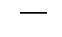 & 17 & 67 & 125 & 194 & 285 & 341 & 264 & - & - & - & 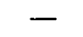 & 1,293 \\
\hline & - & 9 & 5 & 116 & 18 & 24 & 311 & 229 & - & - & - & - & 57 \\
\hline \multirow{2}{*}{ S unflower } & - & 61 & 105 & 189 & 335 & - & - & - & - & 一 & - & - & 690 \\
\hline & $\overline{E 0}$ & 33 & 100 & 1 & 329 & - & - & - & - & - & 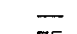 & - & 63 \\
\hline \multirow{2}{*}{ Alfalfa } & 56 & 64 & 171 & 2 & 291 & 333 & 372 & 347 & 264 & 118 & $7 !$ & 56 & 2,360 \\
\hline & 25 & 43 & 141 & 1 & 263 & 301 & 324 & 290 & 229 & 84 & & & 59 \\
\hline Persian & 59 & 78 & 155 & 25 & 26 & 285 & 378 & 一 & & - & 20 & 5 & 48 \\
\hline Clover & 36 & 63 & 137 & 20 & 244 & 275 & 238 & & & - & $y$ & 32 & 2 \\
\hline \multirow{2}{*}{ Sudan Grass } & - & - & 28 & 1 & 267 & 285 & 310 & 297 & & - & & - & 1,325 \\
\hline & - & - & 18 & 120 & 245 & 280 & 297 & 218 & & - & - & - & 1,178 \\
\hline Grape & $\overline{12}$ & 27 & 66 & 117 & 188 & 225 & 247 & 160 & 105 & $\overline{68}$ & $\overrightarrow{18}$ & $\overrightarrow{16}$ & 1,2 \\
\hline
\end{tabular}

Remarks : (1), The upper figures of each rows in the Table show the consumptive use of crops under the present conditions.

(2), The lower figures of each rows in the Table show the consumptive use of crops under the conditions with wind breaker forest.

\section{CONCLUSION}

The most important matter in planning a farm land development project is to estimate an accurate amount of water requirement in the project area. The water requirement consists of the consumptive use of crops and irrigation loss. The former depends on the natural circumstance of the area and the species of crop, such as the location, the elevation, the climate condition, the soil condition, the species and the growth period of the crop, and others. Therefore, the artificial improvments on these factors to save the amount of water requirement is almost impossible. Although windbreak forests or mulch- 
ing may save some of it, is difficult to introduce these countermeasures into the arid zone. The latter is the loss of water from irrigation channels and field surfaces, so that the amount of water requirement will be saved considerably by artificial countermeasures.

The consumptive use of crops for the Sistan project area was estimated by the Blaney-Criddle method and the Penman method. Comparing the results of these two methods, the following items were clarified.

(1) For wheat, which is winter crops, the results by both methods did not have significant difference.

(2) For other crops, there was not significant difference in winter and at the begining of spring, but showed some difference in summer. It would be caused by the effect of wind on the value of evapo-transpiration.

(3) The consumptive use of crops in the Sistan farmland development project should be estimated by the Penman method, considering its climate condition.

The results of this investigation should be confirmed by field experiments. The amount of water requirement was supposed to be over twice the consumptive use of crops because of the water losses due to channel loss, irrigation method or leaching of alkaline soil. These problems will be investigated in future reports.

\section{REFERENCES}

IsraeIsen, 0. W. and V. E. Hansen 1962 Irrigation Principles and Practices. 3rd ed. John Wiley and Sons, New York

Penman, H. L. 1948 Natural evaporation from open water, bare soil and grass. Proc. Roy. Soc., Ser. A, 193: 123-146

Penman, H. L. 1956 Estimating evaporation. Trans. Am. Geopkys. Union, 37: 43-45

Slabbers, P. J. 1969a Determination of water requirements of crops from meteorological data. In "Report to Iran by FAO/UNDP."

Slabbers. P. J. 1969 b Potential evapotranspiration calculations from meteorological and experimental data for Iran. In "Report to Iran by FAO/UNDP."

Blaney, H. F. and W. D. Criddle 1962 Determining consumptive use and irrigation water requirements. Techn. Bul., U. S. D. A., No. 1275: 1-38

Van te Chow 1964 Handbook of Applied Hydrology. McGraw-Hill. New York 